\title{
Influence of nitrogen form on the phytoextraction of cadmium by a newly discovered hyperaccumulator Carpobrotus rossii
}

\author{
Wuxing Liu ${ }^{1,3}$ - Chengjun Zhang ${ }^{3}$ Pengjie $\mathrm{Hu}^{1}$ - Yongming Luo ${ }^{1,2}$ - Longhua $\mathrm{Wu}^{1}$ • \\ Peter Sale $^{3}$ - Caixian Tang ${ }^{3}$
}

Received: 6 June 2015 / Accepted: 11 August 2015 / Published online: 10 September 2015

(C) Springer-Verlag Berlin Heidelberg 2015

\begin{abstract}
Using hyperaccumulator plants is an important method to remove heavy metals from contaminated land. Carpobrotus rossii, a newly found Cd hyperaccumulator, has shown potential to remediate Cd-contaminated soils. This study examined the effect of nitrogen forms on $\mathrm{Cd}$ phytoextraction by $C$. rossii. The plants were grown for 78 days in an acid soil spiked with $20 \mathrm{mg} \mathrm{Cd} \mathrm{kg}^{-1}$ and supplied with $\left(\mathrm{NH}_{4}\right)_{2} \mathrm{SO}_{4}, \mathrm{Ca}\left(\mathrm{NO}_{3}\right)_{2}$, urea, and chicken manure as nitrogen $(\mathrm{N})$ fertilizers. Nitrification inhibitor dicyandiamide (DCD) was applied to maintain the ammonium $\left(\mathrm{NH}_{4}{ }^{+}\right)$form. Nitrogen fertilization increased shoot biomass but decreased root biomass with the highest shoot biomass occurring in the manure treatment. Compared to the no-N control, urea application did not affect shoot $\mathrm{Cd}$ concentration, but increased $\mathrm{Cd}$ content by $17 \%$ due to shoot biomass increase. Chicken manure significantly decreased $\mathrm{CaCl}_{2}$-extractable $\mathrm{Cd}$ in soil, and the $\mathrm{Cd}$ concentration and total $\mathrm{Cd}$ uptake in the plant. Rhizosphere $\mathrm{pH}$ was the highest in the manure treatment and the lowest in the $\mathrm{NH}_{4}{ }^{+}$treatments. The manure and nitrate $\left(\mathrm{NO}_{3}{ }^{-}\right)$treatments tended to have
\end{abstract}

Responsible editor: Elena Maestri

Caixian Tang

C.Tang@latrobe.edu.au

1 Key Laboratory of Soil Environment and Pollution Remediation, Institute of Soil Science, Chinese Academy of Sciences, Nanjing 210008, China

2 Key Laboratory of Coastal Zone Environmental Processes, Yantai Institute of Coastal Zone Research, Chinese Academy of Sciences, Yantai 264003, China

3 Department of Animal, Plant and Soil Sciences, Centre for AgriBioscience, La Trobe University, Melbourne Campus, Bundoora, Victoria 3086, Australia higher rhizosphere $\mathrm{pH}$ than their respective bulk soil $\mathrm{pH}$, whereas the opposite was observed for urea and $\mathrm{NH}_{4}{ }^{+}$treatments. Furthermore, the concentrations of extractable $\mathrm{Cd}$ in soil and $\mathrm{Cd}$ in the plant correlated negatively with rhizosphere $\mathrm{pH}$. The study concludes that urea significantly enhanced the Cd phytoaccumulation by $C$. rossii while chicken manure decreased $\mathrm{Cd}$ availability in soil and thus the phytoextraction efficiency.

Keywords Ammonium $\left(\mathrm{NH}_{4}-\mathrm{N}\right) \cdot$ Animal manure $\cdot \mathrm{Cd}$. Hyperaccumulator $\cdot$ Nitrate $\left(\mathrm{NO}_{3}-\mathrm{N}\right) \cdot$ Phytoremediation

\section{Introduction}

Soil contamination by heavy metals has accelerated during the last few decades. Cadmium is considered as one of the most toxic heavy metals. The high concentrations of Cd observed in many agricultural soils are due to long-term use of phosphate fertilizer and sewage sludge (Stingu et al. 2012). As a nonessential element for living organisms, $\mathrm{Cd}$ is highly mobile in soil-plant systems and can adversely affect both human health and ecosystem functioning (Dwivedi et al. 2014). Therefore, cost-effective procedures are required to remediate $\mathrm{Cd}$ contaminated soils.

Compared with classical remediation techniques, phytoremediation is a cheap and environmentally friendly technique and has attracted attention in recent years. Especially for agricultural soils, concentrations of heavy metals are generally low, and heavy metals are distributed on the surface and can be easily extracted by plant root systems. The task for effective phytoremediation is to identify hyperaccumulator plants with high biomass production. There are numerous reports on the use of hyperaccumulators to remove heavy metals from the soil (Bayramoglu et al. 2012; 
Li et al. 2014). However, the slow growth and low shoot biomass limit the use of many hyperaccumulator plants for a large-scale remediation. Apart from the use of hyperaccumulators with larger biomass, the application of fertilizers or soil amendments to improve soil physicochemical properties and increase plant biomass production is also important for phytoremediation. For example, Wei et al. (2010) found that adding chicken manure significantly increased total Cd extraction by Solanum nigrum although it decreased $\mathrm{Cd}$ concentration in plant tissues.

Nitrogen $(\mathrm{N})$ is an essential macronutrient and is involved in many metabolic processes including the biosynthesis of amino acids and proteins in plants. The application of $\mathrm{N}$ fertilizers is important for biomass production and yield. Nitrate $\left(\mathrm{NO}_{3}{ }^{-}\right)$and ammonium $\left(\mathrm{NH}_{4}^{+}\right)$are the main inorganic $\mathrm{N}$ sources for plants in most agricultural systems. It has been reported how the supply of $\mathrm{NH}_{4}{ }^{+}$enhances $\mathrm{Zn}$ and $\mathrm{Cd}$ uptake by non-hyperaccumulators sunflower and tobacco, which has been related to rhizosphere acidification (Loosemore et al. 2004; Zaccheo et al. 2006). Zaccheo et al. (2006) suggested that manipulation of rhizosphere $\mathrm{pH}$ via the combined use of $\mathrm{NH}_{4}{ }^{+}-\mathrm{N}$ and nitrification inhibitors was an effective way to enhance phytoextraction of $\mathrm{Cd}$ and $\mathrm{Zn}$ from contaminated soils. However, in hydroponic experiments, supplying $\mathrm{NO}_{3}{ }^{-}$ doubled $\mathrm{Cd}$ concentration in the shoots of Noccaea caerulescens, compared with $\mathrm{NH}_{4}{ }^{+}$supply (Xie et al. 2009). Similar results were found for Sedum plumbizincicola in solution culture; $\mathrm{NO}_{3}{ }^{-}$stimulated $\mathrm{Cd}$ uptake by roots, xylem loading, shoot-to-root translocation, and uploading to the leaves and thus enhanced $\mathrm{Cd}$ phytoextraction $(\mathrm{Hu}$ et al. 2013). Monsant et al. (2008) showed that $\mathrm{NO}_{3}{ }^{-}$nutrition improved $\mathrm{Zn}$ phytoextraction in solution culture by increasing the biomass and $\mathrm{Zn}$ concentration of shoots of N. caerulescens.

This soil-based pot experiment compared the effects of manure- $\mathrm{N}$ and different forms of chemical $\mathrm{N}$ supply $\left(\mathrm{NO}_{3}{ }^{-}\right.$ $\mathrm{N}, \mathrm{NH}_{4}{ }^{+}-\mathrm{N}$, and urea-N) on Cd uptake by Carpobrotus rossii, a newly found Australian Cd hyperaccumulator (Zhang et al. 2014). A nitrification inhibitor was used to maintain the $\mathrm{NH}_{4}{ }^{+}$form for plant uptake. We hypothesized that the $\mathrm{NO}_{3}{ }^{-}-\mathrm{N}$ fertilizer form would increase $\mathrm{Cd}$ phytoextraction by $C$. rossii above that of $\mathrm{NH}_{4}{ }^{+}-\mathrm{N}$ forms, in line with earlier research.

\section{Materials and methods}

\section{Cd-contaminated soil}

The soil was collected from the surface layer $(0-15 \mathrm{~cm})$ in the farm of La Trobe University ( $\left.37^{\circ} 43^{\prime} 18^{\prime \prime} \mathrm{S}, 145^{\circ} 02^{\prime} 52^{\prime \prime} \mathrm{E}\right)$. Soil samples were air-dried and ground to pass through a 4$\mathrm{mm}$ sieve. The soil had $\mathrm{pH} 4.99$ (1:5, soil:water), cation exchange capacity $16 \mathrm{cmol} \mathrm{kg}^{-1}$, and the following properties $\left(\mathrm{mg} \mathrm{kg}^{-1}\right)$ : hydrolyzable $\mathrm{N} 158$, available P 11.5 , available K 132, and background $\mathrm{Cd} 0.5$. The soil was spiked with $20 \mathrm{mg} \mathrm{Cd} \mathrm{kg}{ }^{-1}$ by mixing $\mathrm{CdCl}_{2}$ solution thoroughly into the soil. The water content was adjusted to $60 \%$ field capacity. The spiked soil was placed in constant room temperature $\left(25^{\circ} \mathrm{C}\right)$ for 2 weeks to allow added $\mathrm{Cd}$ to equilibrate.

\section{Experimental design and growing conditions}

The experiment consisted of six treatments with three replicates. The treatments were no- $\mathrm{N}$ control, chicken manure, $\mathrm{Ca}\left(\mathrm{NO}_{3}\right)_{2}$, urea $\left[\mathrm{CO}\left(\mathrm{NH}_{2}\right)_{2}\right],\left(\mathrm{NH}_{4}\right)_{2} \mathrm{SO}_{4}$, and $\left(\mathrm{NH}_{4}\right)_{2} \mathrm{SO}_{4}$ plus $\mathrm{NH}_{2} \mathrm{C}(\mathrm{NH})_{2} \mathrm{CN}$ (dicyandiamide, DCD). The $\mathrm{N}$ and DCD were applied to the soil in $100 \mathrm{~mL}$ of water to bring the soil water content to $80 \%$ field capacity. Nitrogen was applied at $20 \mathrm{mg} \mathrm{N} \mathrm{kg}^{-1}$ weekly (total $=200 \mathrm{mg} \mathrm{N} \mathrm{kg}^{-1}$ ). In the $\mathrm{NH}_{4}^{+}+$DCD treatment, DCD was applied at $8 \mathrm{mg} \mathrm{kg}^{-1}$. This application rate of DCD had no significant effect on plant growth and was effective in minimizing nitrification (Monsant et al. 2008). Chicken manure had the following properties: $\mathrm{pH} 7.68$, total $\mathrm{N} 20.1 \mathrm{~g} \mathrm{~kg}^{-1}$, total $\mathrm{Cd}$ $0.55 \mathrm{mg} \mathrm{kg}^{-1}$, available $\mathrm{N} 3430 \mathrm{mg} \mathrm{kg}^{-1}$, available $\mathrm{P}$ $11.5 \mathrm{mg} \mathrm{kg}^{-1}$, and available $\mathrm{K} 150 \mathrm{mg} \mathrm{kg}^{-1}$. The manure was added to the soil at a rate of $1 \% w / w$ (about $200 \mathrm{mg} \mathrm{N} \mathrm{kg}^{-1}$ ) before planting.

A pot experiment was conducted in a glasshouse $(20 \pm$ $5{ }^{\circ} \mathrm{C}$ ) with natural light. Plastic pots were lined with plastic bags and filled with $1.5 \mathrm{~kg}$ air-dried soil. Basal nutrients were applied at the following concentration expressed in milligrams per kilogram of soil: $150 \mathrm{KNO}_{3}, 21 \mathrm{MgSO}_{4} \cdot \mathrm{H}_{2} \mathrm{O}, 150$ $\mathrm{KH}_{2} \mathrm{PO}_{4}, 236 \mathrm{CaCl}_{2} \cdot 2 \mathrm{H}_{2} \mathrm{O}, 18 \mathrm{MnCl}_{2} \cdot 4 \mathrm{H}_{2} \mathrm{O}, 0.67 \mathrm{H}_{3} \mathrm{BO}_{3}$, $10.33 \mathrm{ZnSO}_{4} \cdot 7 \mathrm{H}_{2} \mathrm{O}, 1.42 \mathrm{CuCl}_{2} \cdot 5 \mathrm{H}_{2} \mathrm{O}$, and $0.15 \mathrm{Na}_{2} \mathrm{MoO}_{4}$. $2 \mathrm{H}_{2} \mathrm{O}$. The soil water content was maintained at around $80 \%$ field capacity by watering daily for the experiment duration.

Pre-culture of stem cuttings of $C$. rossii (family Aizoaceae) were grown in plastic nursery cells for 3 weeks (Zhang et al. 2014), and then three uniform rooted stem cuttings were transplanted into each pot. The plants were harvested on day 78.

\section{Plant and soil analyses}

At harvest, shoots were cut at their base, and roots were separated from the soil. Rhizosphere soils were collected by gently shaking off the soil adhering to the roots. The roots were first rinsed with running tap water. The root morphological parameters were determined with a root scanner at $600 \mathrm{dpi}$ (Epson Perfection 4990 Scanner, model J131B, Epson Inc.). Both shoots and roots were then rinsed in distilled water, immersed in $0.1 \mathrm{mM} \mathrm{HCl}$ for approximate $5 \mathrm{~s}$ to remove external metal from the tissue surface, and finally rinsed with distilled water twice. These samples were dried in an oven at $105{ }^{\circ} \mathrm{C}$ 
for $15 \mathrm{~min}$ and then at $70{ }^{\circ} \mathrm{C}$ until completely dry, weighed immediately upon removal from a desiccator, and then ground. Plant materials $(0.5 \mathrm{~g})$ were digested with $7 \mathrm{~mL}$ mixture of concentrated $\mathrm{HNO}_{3}$ and $\mathrm{HClO}_{4}$ (4:1 by volume).

The soil samples taken at the harvest were air-dried and ground to pass through $2 \mathrm{~mm}$. For extractable Cd, air-dried soil was extracted in $0.01 \mathrm{M} \mathrm{CaCl}_{2}$ solution $(1: 10 w / v)$ by shaking end-over-end for $16 \mathrm{~h}$ at $25^{\circ} \mathrm{C}$. The suspensions were then centrifuged at $3000 \mathrm{rpm}$ for $10 \mathrm{~min}$, followed by filtering the supernatant through Whatman No. 1 filter paper. The supernatant was used for $\mathrm{Cd}$ determination.

The concentrations of $\mathrm{Cd}$ in shoot and root digests, and soil extracts were determined using ICP-OES (Varian Vista AX CCD, Australia Pty Ltd.). All plant tissue concentrations were expressed on a dry weight basis. The $\mathrm{pH}$ of the bulk soil and rhizosphere soil was determined in the supernatant using a $\mathrm{pH}$ meter (Thermo Orion 720, USA) after shaking $5 \mathrm{~g}$ soil in $25 \mathrm{~mL} 0.01 \mathrm{M} \mathrm{CaCl}_{2}$ solution, end-over-end for $12 \mathrm{~h}$, and then centrifuging at $2000 \mathrm{rpm}$ for $10 \mathrm{~min}$.

\section{Statistical analysis}

The data were statistically analyzed using Excel and SPSS 16.0 software, and expressed as means \pm standard deviation. The means of the treatments were compared using the Duncan's multiple range tests at $p=0.05$.

\section{Results}

\section{Plant growth}

All plants appeared healthy during the experiment, with differences in shoot growth between the treatments becoming noticeable prior to the harvest at 78 days. The average shoot dry weights ranged from 6.59 to $8.77 \mathrm{~g} \mathrm{pot}^{-1}$. Relative to the no-N control, N fertilization increased shoot weight by $13-$ $33 \%$. Shoot biomass was the highest in the manure treatment while DCD did not affect the shoot dry weight in the $\mathrm{NH}_{4}^{+}$ treatments (Fig. 1a). In contrast, the application of manure and chemical $\mathrm{N}$ decreased the root dry weight by $38-47 \%$ with manure having less effect (Fig. 1a), and hence, there was an increase in the shoot-to-root dry weight ratio. The shoot-toroot dry weight ratio was the highest for the urea and $\mathrm{NH}_{4}^{+}$ treatments and the lowest for the no-N control with no significant differences between the four chemical $\mathrm{N}$ treatments (Fig. 1b).

\section{Root morphology}

Quantitative data of the root morphology are given in Table 1. The decrease in root biomass with the chemical $\mathrm{N}$ treatments coincided with smaller surface areas and shorter cumulative
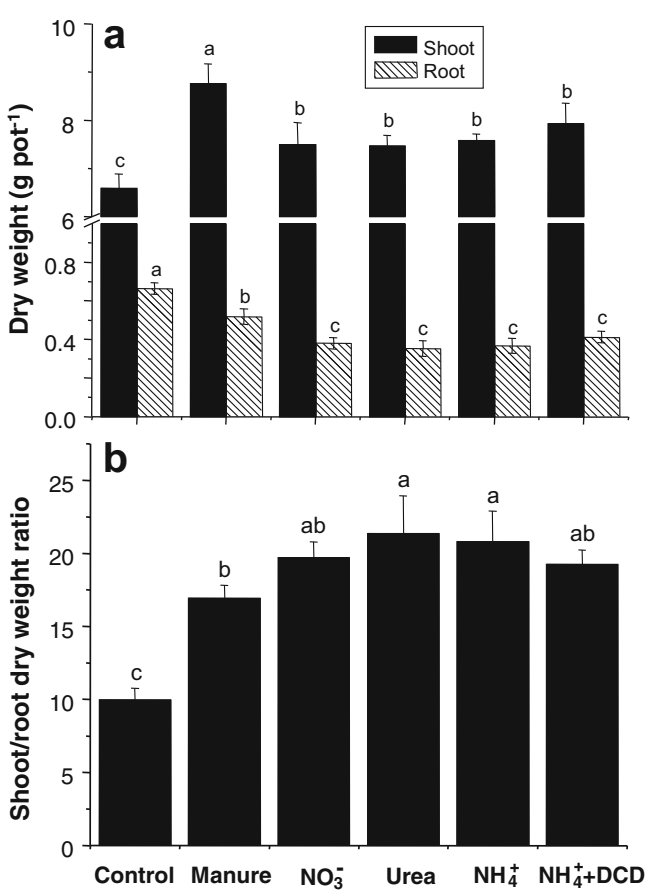

Fig. 1 Effects of $\mathrm{N}$ forms and nitrification inhibitor (DCD) on dry weights of (a) shoots and roots, and (b) shoot-to-root ratio of $C$. rossii grown in a Cd-contaminated soil for 78 days. The control had no added nitrogen. Treatments assigned with different letters are statistically different according to the Duncan's multiple range tests at the $5 \%$ level. Error bars \pm standard deviation $(n=\mathbf{3})$

lengths of roots than the control plants. Furthermore, root length and root surface area were greater in the manure than in the chemical $\mathrm{N}$ treatments. Thicker roots with larger diameters occurred with the $\mathrm{NO}_{3}{ }^{-}, \mathrm{NH}_{4}{ }^{+}$, and urea treatments.

\section{Rhizosphere and bulk soil pH}

The rhizosphere $\mathrm{pH}$ ranged from 4.57 to 5.65 , while the bulk soil pH varied between 4.62 and 5.31 (Fig. 2). The bulk soil $\mathrm{pH}$ was highly correlated with the rhizosphere $\mathrm{pH}(p<0.01)$, indicating that the bulk soil had been affected by the root activity. Rhizosphere $\mathrm{pH}$ was the highest in the manure treatment and the lowest in the $\mathrm{NH}_{4}{ }^{+}$treatments while the manure and $\mathrm{NO}_{3}{ }^{-}$treatments tended to have higher rhizosphere $\mathrm{pH}$ and the urea and $\mathrm{NH}_{4}{ }^{+}$treatments lower rhizosphere $\mathrm{pH}$ than their respective bulk soil $\mathrm{pH}$ readings.

\section{Cadmium in plants}

The concentration of $\mathrm{Cd}$ in shoots varied from $97 \mathrm{mg} \mathrm{kg}^{-1}$ for the manure treatment to $172 \mathrm{mg} \mathrm{kg}^{-1}$ for the urea treatment (Fig. 3a). Compared to the no-N control, the manure and $\mathrm{NO}_{3}{ }^{-}$treatments had lower 
Table 1 Influence of different treatments on root phenotype of C. rossii

\begin{tabular}{|c|c|c|c|}
\hline Treatments & Root length (m plant ${ }^{-1}$ ) & Average diameter $(\mu \mathrm{m})$ & Root surface $\left(\mathrm{cm}^{2}\right.$ plant $\left.^{-1}\right)$ \\
\hline Control & $119 \pm 18 \mathrm{a}$ & $178 \pm 3 c$ & $679 \pm 85 \mathrm{a}$ \\
\hline Manure & $110 \pm 9 \mathrm{a}$ & $180 \pm 5 c$ & $627 \pm 45 \mathrm{a}$ \\
\hline $\mathrm{NO}_{3}^{-}$ & $77 \pm 5 \mathrm{c}$ & $191 \pm 2 \mathrm{a}$ & $466 \pm 30 \mathrm{c}$ \\
\hline Urea & $64 \pm 7 d$ & $191 \pm 8 \mathrm{a}$ & $384 \pm 27 d$ \\
\hline $\mathrm{NH}_{4}^{+}$ & $82 \pm 12 b c$ & $186 \pm 3 b$ & $468 \pm 60 \mathrm{c}$ \\
\hline $\mathrm{NH}_{4}^{+}+\mathrm{DCD}$ & $92 \pm 17 \mathrm{~b}$ & $180 \pm 2 c$ & $513 \pm 85 b$ \\
\hline
\end{tabular}

Data are means \pm standard deviation. Different letters indicate significant differences between treatments at $p<0.05$ while the urea and $\mathrm{NH}_{4}{ }^{+}+\mathrm{DCD}$ treatments had similar concentrations of $\mathrm{Cd}$ in shoots.

The total amount of $\mathrm{Cd}$ in the shoots was significantly enhanced by supply of urea and $\mathrm{NH}_{4}{ }^{+}+\mathrm{DCD}$, but decreased by manure and $\mathrm{NO}_{3}{ }^{-}$treatments, compared to the control (Fig. $3 \mathrm{c}$ ). Thus, the $\mathrm{Cd}$ amount was the highest in the urea and $\mathrm{NH}_{4}{ }^{+}+\mathrm{DCD}$ treatments, followed by the $\mathrm{NH}_{4}{ }^{+}$treatment (similar to control) and then the manure and $\mathrm{NO}_{3}{ }^{-}$treatments (lower than control). The amounts of $\mathrm{Cd}$ in the shoots in the urea and $\mathrm{NH}_{4}{ }^{+}+\mathrm{DCD}$ treatments were 15 and $14 \%$ greater than that in the control, respectively, and were greatest among the $\mathrm{N}$ treatments.

The concentrations of $\mathrm{Cd}$ in the roots were 4-6-fold higher than those in the shoots, ranging from 540 for the manure treatment to $793 \mathrm{mg} \mathrm{kg}^{-1}$ for the urea treatment (Fig. 3a). DCD did not significantly affect the $\mathrm{Cd}$ concentration in roots although $\mathrm{NH}_{4}{ }^{+}+\mathrm{DCD}$ tended to have higher $\mathrm{Cd}$ than the $\mathrm{NH}_{4}{ }^{+}$-alone treatment (Fig. 3a, b). Unlike the shoots, the amount of $\mathrm{Cd}$ in the root did not vary between the $\mathrm{N}$ treatments, with $\mathrm{Cd}$ amount being lower in all $\mathrm{N}$ treatments compared with the control.

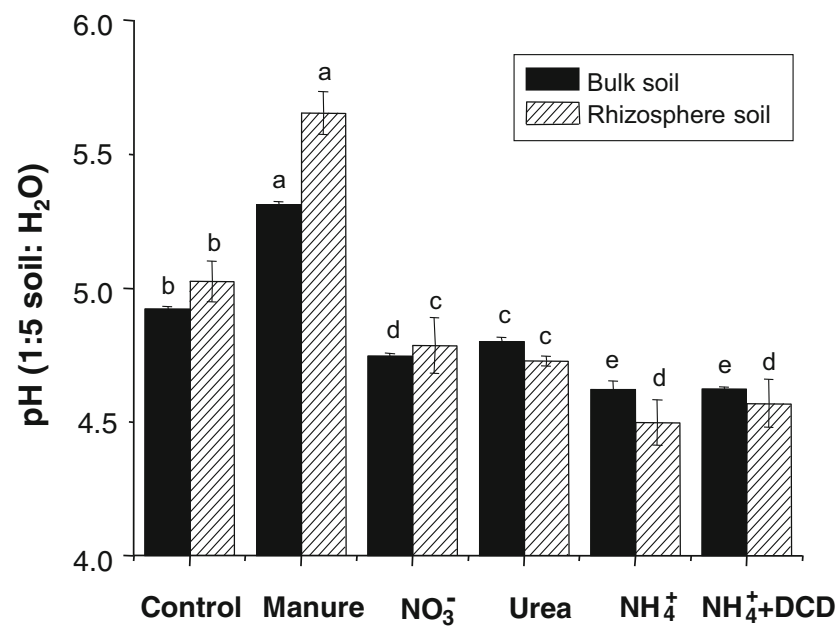

Fig. 2 Effects of $\mathrm{N}$ forms and manure addition on rhizosphere and bulk soil $\mathrm{pH}$ of $C$. rossii grown in a Cd-contaminated soil for 78 days. Means for the same type of soil with different letters are statistically different according to the Duncan's multiple range tests at the $5 \%$ level. Error bars \pm standard deviation $(n=3)$
The shoot-to-root ratios of $\mathrm{Cd}$ concentration and content for the $\mathrm{NH}_{4}{ }^{+}, \mathrm{NH}_{4}{ }^{+}+\mathrm{DCD}$ and urea treatments were significantly higher than those for the manure and $\mathrm{NO}_{3}{ }^{-}$treatments, indicating that $\mathrm{NH}_{4}^{+}$and urea enhanced $\mathrm{Cd}$ translocation from the roots to shoots compared with that of $\mathrm{NO}_{3}{ }^{-}$and manure (Fig. 3c, d). The highest shoot-to-root ratio of $\mathrm{Cd}$ concentration occurred in the control treatment.

Given the treatment effects on rhizosphere $\mathrm{pH}$ (Fig. 2) and Cd concentrations in shoots (Fig. 3a), it was thus not surprising that the $\mathrm{Cd}$ concentration in shoots correlated negatively with rhizosphere $\mathrm{pH}$ across treatments $(p<0.01)$ (Fig. 4).

\section{Extractable Cd in bulk soil}

Compared to the control, most of $\mathrm{N}$ fertilizers tended to increase the concentration of $\mathrm{CaCl}_{2}$-extractable $\mathrm{Cd}$ but the only significant difference was recorded with the $\mathrm{NH}_{4}{ }^{+}+\mathrm{DCD}$ treatment (Fig. 5). By contrast, manure amendment strongly decreased the concentration of $\mathrm{CaCl}_{2}$-extractable $\mathrm{Cd}$ by a factor of 2 compared to the control.

\section{Discussion}

This study demonstrated that $C$. rossii could accumulate $\mathrm{Cd}$ to a concentration of over $170 \mathrm{mg} \mathrm{kg}^{-1}$ in the shoots, and that ammonium enhanced while nitrate decreased the $\mathrm{Cd}$ phytoextraction by this species when grown in the acid soil. C. rossii is a succulent glabrous halophytic perennial commonly found in the coastal fore-dunes of southern Australia (Venning 1988). It was shown to hyperaccumulate $\mathrm{Cd}$ and to be more tolerant to Cd than most species (Zhang et al. 2014). Other $\mathrm{Cd}$ hyperaccumulators have been identified, notably N. caerulescens (Robinson et al. 1998), Arabidopsis halleri (Bert et al. 2002), Rorippa globosa (Sun et al. 2007), S. nigrum (Wei et al. 2006), Sedum alfredii (Yang et al. 2004), Viola baoshanensis (Liu et al. 2004), and S. plumbizincicola (Li et al. 2014), but none of these plants are native to Australia (van der Ent et al. 2013). In combination with its easy growing, and salt- and drought-tolerant 
Fig. 3 Effects of $\mathrm{N}$ form and manure addition on (a) $\mathrm{Cd}$ concentrations in shoots and roots, (b) shoot-to-root $\mathrm{Cd}$ concentration ratio, (c) the amount of $\mathrm{Cd}$ in shoots and roots, and (d) shoot-to-root $\mathrm{Cd}$ content ratio of C. rossii grown in a $\mathrm{Cd}-$ contaminated soil for 78 days. Treatment means with different letters within a tissue type are statistically different according to the Duncan's multiple range tests at the $5 \%$ level. Error bars \pm standard deviation $(n=3)$
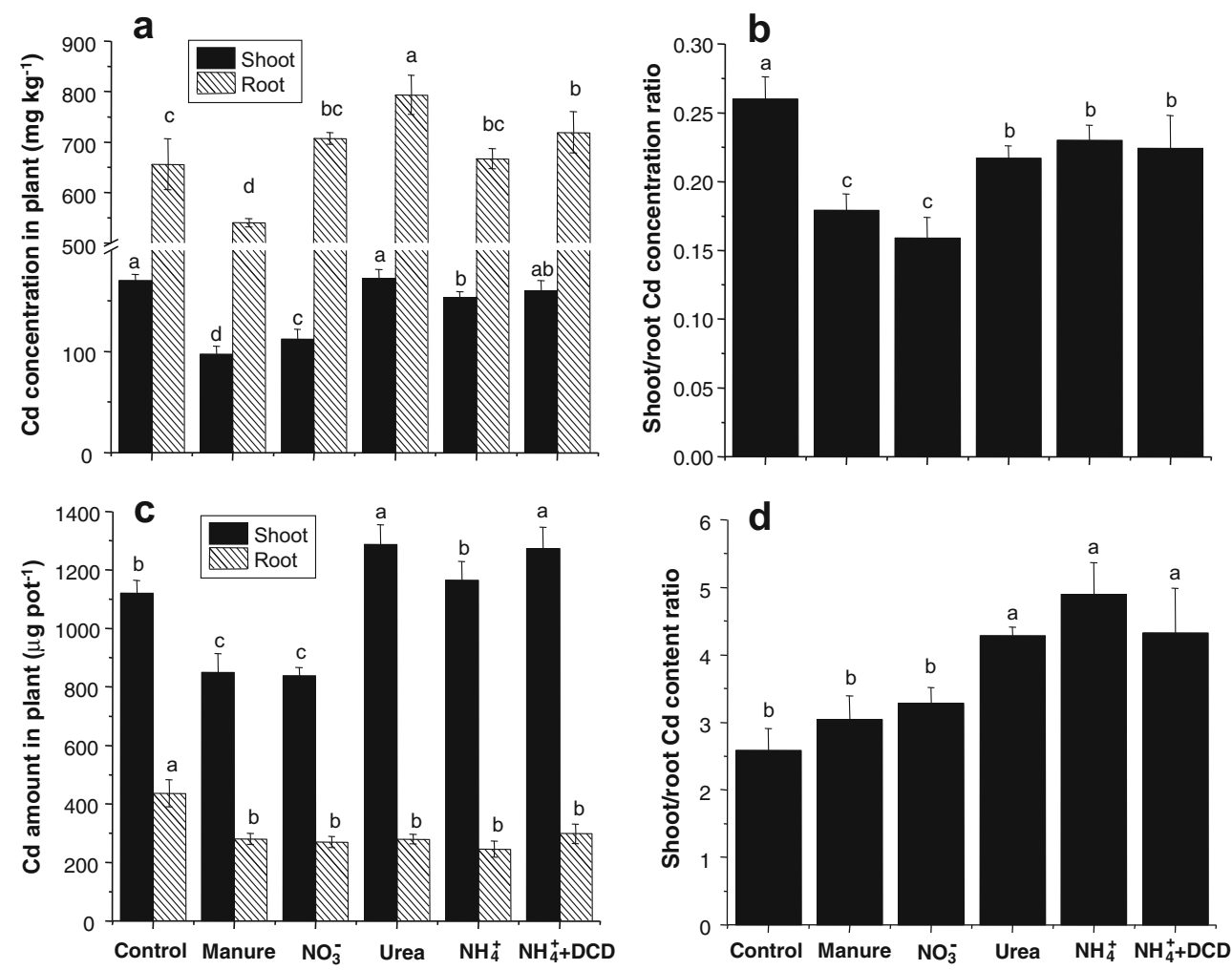

traits, this native species, C. rossii, could be a promising candidate for phytoremediation of Cd-contaminated soils, especially in drought-prone areas and soils with high salinity (Zhang et al. 2014).

Nitrogen fertilization is believed helpful for phytoremediation of heavy metals because it enhances plant growth, influences the cellular charge balance (Marschner and Römheld 1994) and helps to produce proteins which form complexes with metals to affect translocation and/or storage or are antioxidative enzymes to reduce the level of oxidation

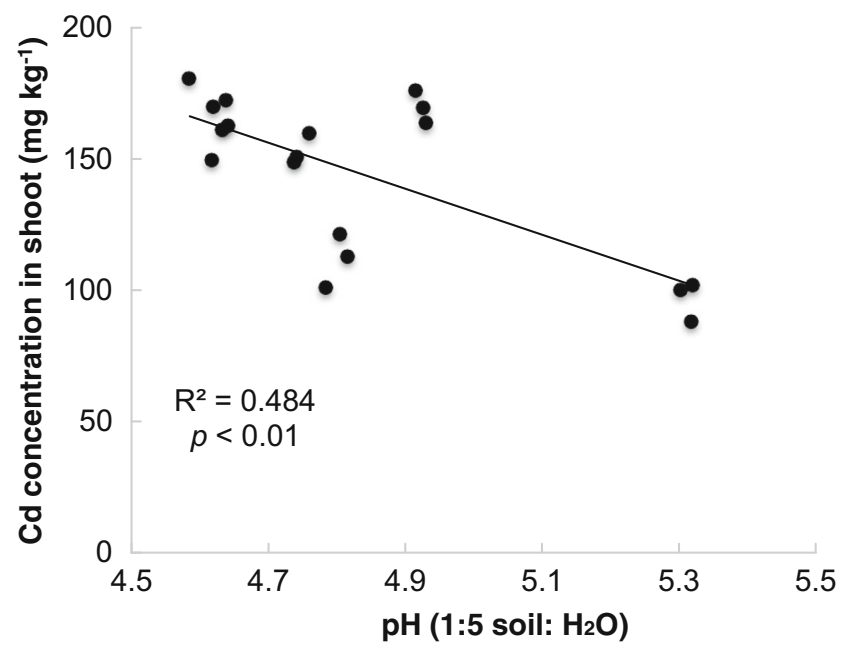

Fig. 4 Relationship between rhizosphere $\mathrm{pH}$ and $\mathrm{Cd}$ concentration in shoots for C. rossii grown in a Cd-contaminated soil for 78 days caused by metals (Sarwar et al. 2010). Nitrogen fertilizers, usually in the form of $\mathrm{NH}_{4}{ }^{+}, \mathrm{NO}_{3}{ }^{-}$, urea, or organic nitrogen (manure), are used to enhance plant biomass and the phytoextraction efficiency of contaminants from soils (Giansoldati et al. 2012). This study showed that all forms of nitrogen could efficiently increase plant biomass to a similar extent. Although the highest $\mathrm{Cd}$ concentrations in shoots were observed in the control, urea, and $\mathrm{NH}_{4}{ }^{+}+\mathrm{DCD}$ treatments, the highest amounts of $\mathrm{Cd}$ were obtained in the urea and $\mathrm{NH}_{4}{ }^{+}+$

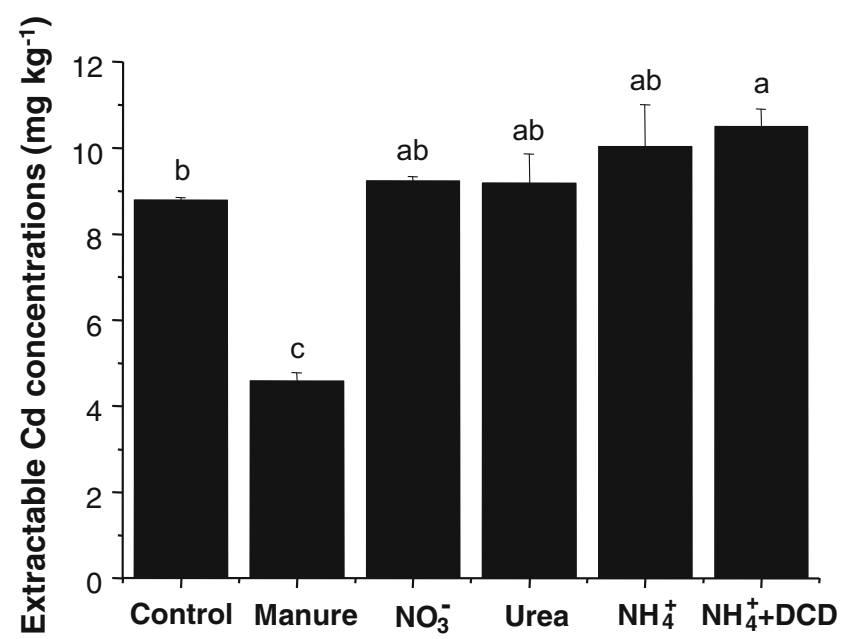

Fig. 5 Concentrations of $\mathrm{CaCl}_{2}$-extractable $\mathrm{Cd}$ in bulk soil receiving different treatments. Means with different letters are statistically different according to the Duncan's multiple range tests at the $5 \%$ level. Error bars standard deviation $(n=3)$ 
DCD treatments due to higher biomass production in these treatments compared to the control (Fig. 3).

Nitrate and $\mathrm{NH}_{4}^{+}$are the two main forms of inorganic $\mathrm{N}$ that are taken up by plants. Since N accounts for $80 \%$ of the total nutrients taken up by roots, the charge of these $\mathrm{N}$ ions has a strong effect on charge balance in root epidermal cells (Marschner and Römheld 1994). Physiologically, the uptake of $\mathrm{NO}_{3}{ }^{-}$and $\mathrm{NH}_{4}{ }^{+}$induces the release of $\mathrm{OH} / \mathrm{HCO}_{3}{ }^{-}$and $\mathrm{H}^{+}$ ions, respectively. This was shown in the present study where the rhizosphere $\mathrm{pH}$ was lower in the $\mathrm{NH}_{4}{ }^{+}$than in the $\mathrm{NO}_{3}{ }^{-}$ treatment (Fig. 2). Ammonium nutrition causes rhizosphere acidification which in turn increases metal bioavailability in soil and hence plant uptake (Zaccheo et al. 2006). Thus, rhizosphere acidification might explain the higher concentration and phytoextraction of Cd by $C$. rossii grown in the $\mathrm{NH}_{4}^{+}$than the $\mathrm{NO}_{3}{ }^{-}$treatment, with much lower rhizosphere $\mathrm{pH}$ in the $\mathrm{NH}_{4}{ }^{+}$treatments. This is also supported by the strong negative relationship between $\mathrm{Cd}$ concentration in shoots and rhizosphere $\mathrm{pH}$ (Fig. 4), and the higher Cd phytoextraction with the $\mathrm{NH}_{4}{ }^{+}+\mathrm{DCD}$ than the $\mathrm{NH}_{4}^{+}$-alone treatment (Fig. 3) because $\mathrm{DCD}$ is able to inhibit nitrification and thereby decrease $\mathrm{NO}_{3}{ }^{-}$concentration in soil (Arnamwong et al. 2015). Our results are consistent with the study of Zaccheo et al (2006) who showed that the application of $\mathrm{NH}_{4}{ }^{+}$together with nitrification inhibitor DMPP resulted in higher $\mathrm{Cd}$ uptake compared to $\mathrm{NO}_{3}^{-}$, in the shoot of non-hyperaccumulator sunflower grown in contaminated soils.

The present study showed that manure addition increased the production of shoot biomass but decreased the concentration of extractable $\mathrm{Cd}$ in soil and $\mathrm{Cd}$ concentration in plants. A number of studies have also shown that the application of organic materials (e.g., farmyard manure, compost, peat soil) resulted in a decrease in $\mathrm{Cd}$ concentration in plants (e.g., corn, wheat, radish, alfalfa, and Indian mustard) (Wei et al. 2010). In general, organic amendments such as animal manures contain a high proportion of humidified organic matter, which forms strong complexes with $\mathrm{Cd}$, resulting in $\mathrm{Cd}$ immobilization and decreased $\mathrm{Cd}$ bioavailability in the soil (Putwattana et al. 2010). Additionally, manures often contain high contents of dissolved organic matter which forms soluble organic-metal complexes (Bolan et al. 2003a; Vaca-Paulin et al. 2006) that reduce metal availability to plants (Bolan et al. 2003b). Soluble organic-Cd complexes are also likely to have contributed to the lower phytoextraction by the manure treatment.

All $\mathrm{N}$ fertilizers reduced root biomass (Fig. 1a), and this is likely to be in response to the alleviation of $\mathrm{N}$ deficiency in the soil. The chemical $\mathrm{N}$ treatments resulted generally in shorter, thicker roots with less surface area compared with the control and manure treatments (Table 1). An increased biomass allocation to the roots is a common phenomenon in many plant species in response to $\mathrm{N}$ deficiency. It is suggested that $\mathrm{N}$ deficiency initiates transcriptional changes that lead to the accumulation of carbohydrates in the shoots and increase the translocation of sucrose to the roots (Hermans et al. 2006). It could be argued that small root systems in the $\mathrm{N}$-amended treatments would not favor the uptake of heavy metals in soil. For example, Lombi et al. (2000) reported the greater root system in the French ecotype of $N$. caerulescens (root:shoot $=0.21$ ) than the Prayon ecotype (root:shoot= 0.12 ) could be partly responsible for the higher Cd uptake in roots and accumulation in shoots of the French ecotype. However, in this study, the $\mathrm{NH}_{4}{ }^{+}+\mathrm{DCD}$ and urea treatments resulted in higher $\mathrm{Cd}$ uptake by shoots compared to the control and yet had significantly smaller root systems. Thus, soil factors such as rhizosphere $\mathrm{pH}$ and $\mathrm{Cd}$ extractability were more important in determining $\mathrm{Cd}$ extraction from the soil than root morphology.

Nitrogen form also appeared to affect $\mathrm{Cd}$ translocation from roots to shoots of $C$. rossii. It is evident that the shootto-root ratio of $\mathrm{Cd}$ concentration and content was significantly higher in the urea and $\mathrm{NH}_{4}{ }^{+}$treatments than the $\mathrm{NO}_{3}{ }^{-}$treatment (Fig. 3c, d), indicating that urea and $\mathrm{NH}_{4}{ }^{+}$nutrition stimulates the translocation of $\mathrm{Cd}$ from roots to shoots to a higher extent compared with $\mathrm{NO}_{3}{ }^{-}$nutrition. Wang et al. (2010) also found the shoot-to-root Cd concentration in mustard grown in pots was higher with $\mathrm{NH}_{4}{ }^{+}$than with $\mathrm{NO}_{3}{ }^{-}$ treatment. The mechanism by which $\mathrm{N}$ form affects the $\mathrm{Cd}$ translocation is unclear. In $N$. caerulescens, $\mathrm{NO}_{3}{ }^{-}$nutrition enhanced the formation of organic acids while $\mathrm{NH}_{4}{ }^{+}$nutrition increased the formation of amino acids (White-Monsant and Tang 2013). The form of $\mathrm{N}$ in this study might have also affected the concentrations of different metabolites in the xylem of $C$. rossii and thereby affected the $\mathrm{Cd}$ transport from the roots to the shoots. However, $\mathrm{N}$ form did not affect $\mathrm{Zn}$ speciation in shoots, roots, or xylem even though $\mathrm{Zn}$ accumulation in the shoots was enhanced (Monsant et al. 2008, 2011).

The results from this study, where $\mathrm{NH}_{4}{ }^{+}-\mathrm{N}$ forms resulted in greater $\mathrm{Cd}$ uptake by shoots than $\mathrm{NO}_{3}{ }^{-}-\mathrm{N}$, mean that our hypothesis is rejected. The results are inconsistent with those of Xie et al. (2009) and Hu et al. (2013). By using a positronemitting ${ }^{107} \mathrm{Cd}$ tracer, Hu et al. (2013) showed that Cd transport was 1.5-fold and 3.7-fold faster in the roots and shoots, respectively, in the Cd hyperaccumulator $S$. plumbizincicola supplied with $\mathrm{NO}_{3}{ }^{-}$than with $\mathrm{NH}_{4}{ }^{+}$. The concentration of $\mathrm{Cd}$ was 2.63 times higher in shoots of the $\mathrm{NO}_{3}{ }^{-}$- than $\mathrm{NH}_{4}{ }^{+}$-fed plants in nutrient solution. Similarly, Xie et al. (2009) showed in hydroponic experiments that compared with $\mathrm{NH}_{4}{ }^{+}$nutrition, $\mathrm{NO}_{3}{ }^{-}$nutrition doubled shoot $\mathrm{Cd}$ concentrations and increased shoot $\mathrm{Cd}$ accumulation by $2.6-8$-fold in $N$. caerulescens. The reasons for the discrepancy in these studies can be attributed to the rhizosphere effect in this soilbased study. This effect, where the rhizosphere $\mathrm{pH}$ differs with $\mathrm{N}$ form (Fig. 2), is dissipated in solution culture, as ions can freely diffuse away from the root surface in the culture solution, which cannot happen in the soil. Thus, the study 
highlights the importance of soil-based experiments, compared to those using solution culture, when investigating $\mathrm{Cd}$ phytoextraction from Cd-contaminated soils.

\section{Conclusions}

This study aimed at testing chemical $\mathrm{N}$ fertilizers and manure to evaluate the influence of $\mathrm{N}$ form on $\mathrm{Cd}$ phytoextraction using Australian native species C. rossii, a $\mathrm{Cd}$ hyperaccumulator. The addition of $\mathrm{N}$ fertilizers significantly enhanced shoot biomass production, particularly manure application resulted in the highest shoot biomass. However, manure application significantly decreased $\mathrm{Cd}$ availability in soil and hence plant $\mathrm{Cd}$ phytoextraction efficiency. Although the four chemical $\mathrm{N}$ treatments resulted in similar shoot and root biomass production, the highest efficiency of $\mathrm{Cd}$ phytoextraction by $C$. rossii was in the urea- and $\mathrm{NH}_{4}{ }^{+}+$ DCD-amended soils. Thus, this study suggests that urea would be a good $\mathrm{N}$ source to enhance $\mathrm{Cd}$ phytoextraction using $C$. rossii. Future work is required to compare the effect of $\mathrm{N}$ form on metal extraction with other plant species and to validate the efficiency of $C$. rossii under field conditions.

Acknowledgments We thank the Key Projects in the National Science \& Technology Pillar Program (2015BAD05B04), National High Technology Research and Development Program of China (863 Program) (2012AA06A204), Jiangsu Provincial Natural Science Foundation of China (BK2012891), and Australian Research Council Linkage Project (LP100100800) for the financial support. We also thank anonymous reviewers for their valuable comments.

\section{References}

Arnamwong S, Wu L, Hu P, Yuan C, Thiravetyan P, Luo Y, Christie P (2015) Phytoextraction of cadmium and zinc by Sedum plumbizincicola using different nitrogen fertilizers, a nitrification inhibitor and a urease inhibitor. Int J Phytoremediation 17:382-390

Bayramoglu G, Arica MY, Adiguzel N (2012) Removal of Ni (II) and Cu (II) ions using native and acid treated $\mathrm{Ni}$-hyperaccumulator plant Alyssum discolor from Turkish serpentine soil. Chemosphere 89: 302-309

Bert V, Bonnin I, Saumitou-Laprade P, De Laguérie P, Petit D (2002) Do Arabidopsis halleri from nonmetallicolous populations accumulate zinc and cadmium more effectively than those from metallicolous populations? New Phytol 155:47-57

Bolan N, Adriano D, Mani S, Khan A (2003a) Adsorption, complexation, and phytoavailability of copper as influenced by organic manure. Environ Toxicol Chem 22:450-456

Bolan NS, Adriano DC, Natesa R, Koo BJ (2003b) Effects of organic amendments on the reduction and phytoavailability of chromate in mineral soil. J Environ Qual 32:120-128

Dwivedi G, Upadhyay S, Mishra A, Kumar Singh A (2014) Hyper accumulation of cadmium in Solanum nigrum L. and their effects on phyto-chemicals and antioxidant enzymatic activities. Int J Pharm Sci Res 5:1424-1430
Giansoldati V, Tassi E, Morelli E, Gabellieri E, Pedron F, Barbafieri M (2012) Nitrogen fertilizer improves boron phytoextraction by Brassica juncea grown in contaminated sediments and alleviates plant stress. Chemosphere 87:1119-1125

Hermans C, Hammond JP, White PJ, Verbruggen N (2006) How do plants respond to nutrient shortage by biomass allocation? Trends Plant Sci 11:610-617

Hu P, Yin YG, Ishikawa S, Suzui N, Kawachi N, Fujimaki S, Igura M, Yuan C, Huang J, Li Z (2013) Nitrate facilitates cadmium uptake, transport and accumulation in the hyperaccumulator Sedum plumbizincicola. Environ Sci Pollut Res 20:6306-6316

Li Z, Wu L, Hu P, Luo Y, Zhang H, Christie P (2014) Repeated phytoextraction of four metal-contaminated soils using the cadmium/zinc hyperaccumulator Sedum plumbizincicola. Environ Pollut 189:176-183

Liu W, Shu W, Lan C (2004) Viola baoshanensis, a plant that hyperaccumulates cadmium. Chin Sci Bull 49:29-32

Lombi E, Zhao FJ, Dunham SJ, McGrath SP (2000) Cadmium accumulation in populations of Thlaspi caerulescens and Thlaspi goesingense. New Phytol 145:11-20

Loosemore AN, Straczek A, Hinsinger P, Jaillard B (2004) Zinc mobilisation from a contaminated soil by three genotypes of tobacco as affected by soil and rhizosphere pH. Plant Soil 260:19-32

Marschner H, Römheld V (1994) Strategies of plants for acquisition of iron. Plant Soil 165:261-274

Monsant AC, Tang C, Baker A (2008) The effect of nitrogen form on rhizosphere soil $\mathrm{pH}$ and zinc phytoextraction by Thlaspi caerulescens. Chemosphere 73:635-642

Monsant AC, Kappen P, Wang Y, Pigram PJ, Baker AJ, Tang C (2011) In vivo speciation of zinc in Noccaea caerulescens in response to nitrogen form and zinc exposure. Plant Soil 348:167-183

Putwattana N, Kruatrachue M, Pokethitiyook P, Chaiyarat R (2010) Immobilization of cadmium in soil by cow manure and silicate fertilizer, and reduced accumulation of cadmium in sweet basil (Ocimum basilicum). Sci Asia 36:349-354

Robinson BH, Leblanc M, Petit D, Brooks RR, Kirkman JH, Gregg PE (1998) The potential of Thlaspi caerulescens for phytoremediation of contaminated soils. Plant Soil 203:47-56

Sarwar N, Saifullah, Malhi SS, Zia MH, Naeem A, Bibi S, Farid G (2010) Role of mineral nutrition in minimizing cadmium accumulation by plants. J Sci Food Agric 90:925-937

Stingu A, Volf I, Popa VI, Gostin I (2012) New approaches concerning the utilization of natural amendments in cadmium phytoremediation. Ind Crops Prod 35:53-60

Sun Y, Zhou Q, Wei S, Ren L (2007) Growth responses of the newlydiscovered Cd-hyperaccumulator Rorippa globosa and its accumulation characteristics of $\mathrm{Cd}$ and $\mathrm{As}$ under joint stress of $\mathrm{Cd}$ and $\mathrm{As}$. Front Environ Sci Eng China 1:107-113

Vaca-Paulin R, Esteller-Alberich MV, Lugo de la Fuente J, ZavaletaMancera HA (2006) Effect of sewage sludge or compost on the sorption and distribution of copper and cadmium in soil. Waste Manag 26:71-81

van der Ent A, Baker AJ, Reeves RD, Pollard AJ, Schat H (2013) Hyperaccumulators of metal and metalloid trace elements: facts and fiction. Plant Soil 362:319-334

Venning J (1988) Flora of Australia Vol. 4: Phytolaccaceae to Chenopodiaceae. Australian Government Publishing Service

Wang Y, Ai S, Li M, Yang S, Yao J, Tang M, Zeng Z (2010) Effect of nitrogen fertilization on cadmium translocation in soil-mustard system. Chinese J Eco-Agric 18:649-653 (in Chinese)

Wei S, Li Y, Zhou Q, Srivastava M, Chiu S, Zhan J, Wu Z, Sun T (2010) Effect of fertilizer amendments on phytoremediation of Cdcontaminated soil by a newly discovered hyperaccumulator Solanum nigrum L. J Hazard Mater 176:269-273 
Wei S, Zhou Q, Koval PV (2006) Flowering stage characteristics of cadmium hyperaccumulator Solanum nigrum L. and their significance to phytoremediation. Sci Total Environ 369:441-446

White-Monsant A, Tang C (2013) Organic acids are not specifically involved in the nitrate-enhanced $\mathrm{Zn}$ hyperaccumulation mechanism in Noccaea caerulescens. Environ Exp Bot 91:12-21

Xie H, Jiang R, Zhang F, McGrath S, Zhao F (2009) Effect of nitrogen form on the rhizosphere dynamics and uptake of cadmium and zinc by the hyperaccumulator Thlaspi caerulescens. Plant Soil 318:205215
Yang X, Long X, Ye H, He Z, Calvert D, Stoffella P (2004) Cadmium tolerance and hyperaccumulation in a new Zn-hyperaccumulating plant species (Sedum alfredii Hance). Plant Soil 259:181-189

Zaccheo P, Crippa L, Pasta VDM (2006) Ammonium nutrition as a strategy for cadmium mobilisation in the rhizosphere of sunflower. Plant Soil 283:43-56

Zhang C, Sale PW, Doronila AI, Clark GJ, Livesay C, Tang C (2014) Australian native plant species Carpobrotus rossii (Haw.) Schwantes shows the potential of cadmium phytoremediation. Environ Sci Pollut Res 21:9843-9851 